\title{
The Stela of Haremwia Chief of the Provisioning Sector of the Temple Workshop (CG 34079 / JE 22011)
}

\author{
Amgad Joseph
}

\begin{abstract}
This article is devoted to the description and analysis of the limestone stela of Haremwia from Abydos. It was on display in the Egyptian Museum, Cairo (CG 34079 / JE 22011) and is currently in the storerooms of the Grand Egyptian Museum, Giza. It dates to the period from the mid to the late Eighteenth Dynasty, New Kingdom, and probably from the reign of Amenhotep III, on the basis of its stylistic, iconographic, and epigraphic details. It is extremely well preserved and most of the colours are intact, apart from some damage to the bottom. The stela records a significant title of Haremwia, namely hry $\breve{s} n^{c}$ $n t 3 w^{\top} b t$, 'chief of the provisioning sector of the temple workshop'. The importance of this stela, above all, is that it records the first attestation of this title on Egyptian monuments. Furthermore, it records Asiatic names of foreign origin for family members. The offering formula in the first register is very interesting due to the retrograde orientation of its hieroglyphic inscription. The author describes the stela, deals with its individual idiosyncrasies, inscriptions, iconographic and phraseological traits, and focuses on the titles and professions of its individuals.
\end{abstract}

Keywords: New Kingdom Egypt, stela, the Temple of Osiris, Abydos, temple workshop

Amgad Joseph, Faculty of Tourism and Hotel Management, Helwan University, Cairo; amgadjoseph@yahoo.com; (D) 0000-0001-6147-5913

The stela of Haremwia was found at the southern side of the central necropolis in Abydos. ${ }^{1}$ It was probably set up near the Terrace of the Great God, overlooking the Temple of Osiris. It is a pointed-topped stela made of painted limestone and measures $36 \mathrm{~cm}$ in height and $34 \mathrm{~cm}$ in width (Fig. 1). ${ }^{2}$ The figures and hieroglyphic inscriptions are carved in sunk relief with painted incised lines. The central panneau is framed by round-topped incised

\footnotetext{
${ }^{1}$ Lacau 1926: 126-127, Pl. 40; Mariette 1880: 390, no. 1073; Helck 1958: 259, n. 5; PM V, 264.

${ }^{2}$ For other examples of pointed-topped stelae, see the limestone stela of Nefertiri from Memphis in the Field Museum of Natural History (inv. no. 31652) dating to the Nineteenth or Twentieth Dynasty (Allen 1936: 35-36, n. 1, Pl. 14).
} 
double lines. The triangular top is carved in sunk relief with the combined hieroglyphic

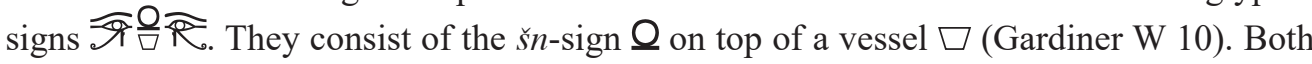
are flanked by two $w \underline{d} 3 t$-eyes of Horus, ${ }^{3}$ which symbolise protection and the eternal cycle of the sun. ${ }^{4}$ An incised horizontal line divides the stela into two registers with eleven human figures as well as the figure of Osiris, in sunk relief and showing considerable detail. The top register shows the main figure, Haremwia, and his son Amenemopet behind him. They are shown standing before Osiris, with upraised arms in an adoration pose and with the right leg stepping forward. The second register shows nine members of the family of Haremwia with hieroglyphic captions giving their names and filiation. This register is divided into two parts by a vertical incised line. Between the horizontal lines of the bottom margins, beneath the second register, are hieroglyphic inscriptions giving the names of some family members. The nine figures are divided into two groups facing each other. Only the figure of the brewer Amenemopet, is shown alone on the left, outside the incised margins of the stela, behind the displayed individuals.

\section{SCENES AND INSCRIPTIONS}

\section{FIRST REGISTER}

The first (upper) register, as already mentioned above, shows the figure of Osiris in his usual mummy form, enthroned on the left and facing right (Fig. 2). He is shown seated on a throne with a low backrest inside his $k 3 r$-shrine. The latter has a sloped ceiling painted reddish and bulging at the front. ${ }^{5}$ Osiris wears his characteristic white crown, wsh-collar and a long-curved beard. He is wrapped in a close-fitting white garment. The counterpoise of his collar is hanging down his back. Both his hands emerge from the garment, clasping a $h q$ 3-sceptre and $n h$ 3h 3-flail.

The $k 3 r$-shrine of Osiris is reserved solely for the god. In some representations, he is shown enthroned inside it, accompanied by Isis and/or Nephthys. ${ }^{6}$ The shrine plays a significant

3 The representations of the two $w d \underline{d} 3$-eyes and the $\check{s} n$-sign, on the lunette of curved top stelae, made their first appearance as early as the fifteenth regnal year of king Senwosret III. Thus, the $w d$ d 3 -eyes mark the dating of the second half of the Middle Kingdom stelae; see: stelae Cairo CG 20537, 20556, 20598, 20613, 20623; Lange, Schäfer 1902: 144-145, 188-189, 237-239, 252-253, 262-263. See also: Hodjash, Berlev 1975: 7. 5-18. These are also shown on stela Cairo CG 34055; see: Lacau 1926: Pl. 33; see also: Fischer 1976: 46-47.

4 Westendorf 1966: 35. For further information about the two $w \underline{d} 3 t$-eyes on the lunette of other stelae, see: Hermann 1940: 53-57.

5 The shrine is listed in Gardiner's sign list no. O $18 \cong$; see: Gardiner 1957: 494; Wb V, 107, 12-15. Ptah is shown inside this shrine on some stelae; see, for instance, the Nineteenth Dynasty stela of Penbuy in the British Museum, London (EA1466); Bierbrier (Ed.) 1982: 31-32, P1. 73. Ptah is also shown inside this shrine on the Nineteenth Dynasty stelae of Pashed and Baki (EA262 and EA265); see: James (Ed.) 1970: 40-41, P1. 35 (1-2); see also the Nineteenth Dynasty stela of Neferrenpet in Roemer-Pelizaeus Museum, Hildesheim (inv. no. 1892); PM IV, 26; Roeder 1926: 61, P1. 4 (2); Holmberg 1946: 15, 241, Fig. 14.

${ }^{6}$ Isis is shown behind Osiris inside the $k 3 r$-shrine in the first scene of the Twenty-first Dynasty mythological papyrus of Padiamen, the prophet of Amun; see: Piankoff 1957: 109, Pl. 10. 


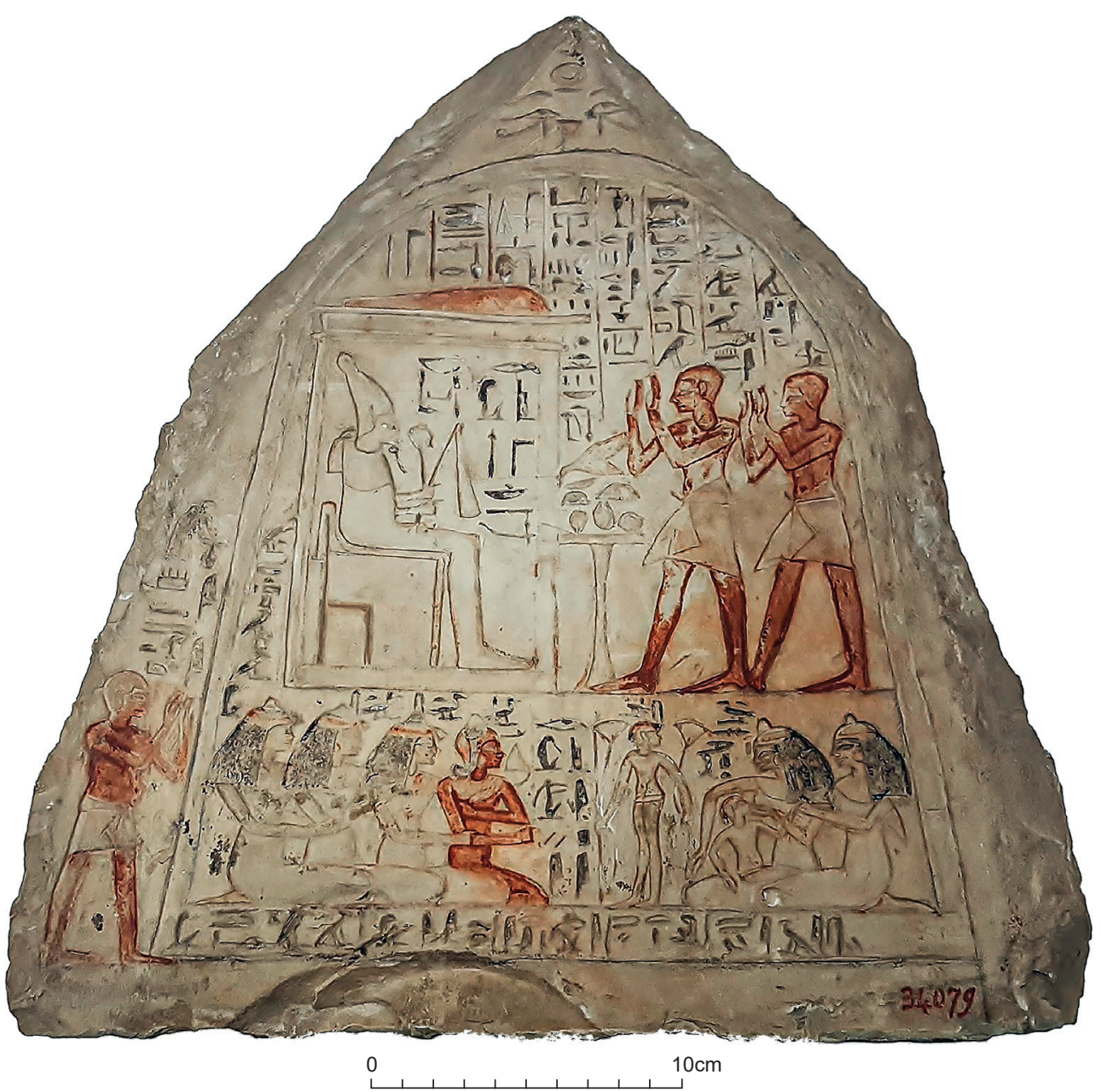

1. Stela of Haremwia, CG 34079 / JE 22011 (C Egyptian Museum, Cairo; courtesy of the Egyptian Museum, Cairo and the Grand Egyptian Museum, Giza).

role in the union between Re and Osiris. Thus, the light of the sun god dwells inside Osiris' corpse within the shrine, allowing his $b a$ to follow Re out of the Netherworld. ${ }^{7}$ Like Atum in the Shu Spell 335 of the Coffin Texts, ${ }^{8}$ Osiris resides in a $k 3 r$-shrine guarded by protective deities (ntrw pw h3w k3r), who also represent the seven spirits guarding Osiris during the hourly vigil in the Netherworld. ${ }^{9}$ The shape of the $k 3 r$-shrine is reminiscent of the pre-dynastic $p r$-wr-sanctuary of Upper Egypt, which represents the prototype for

${ }^{7}$ For the $k 3 r$-shrine as the place where the unification of Re and Osiris occurs, see: P. Berlin 3049, col. 17, 11. 1-2; Gülden 2001: 78-79.

${ }^{8}$ CT IV, 222c-226a [335]; Faulkner 1973: 263; Willems 1997: 364. For this spell in relation to Osiris, see: Smith 2017: 237, 248, 304.

${ }^{9}$ Willems 1997: 364. 


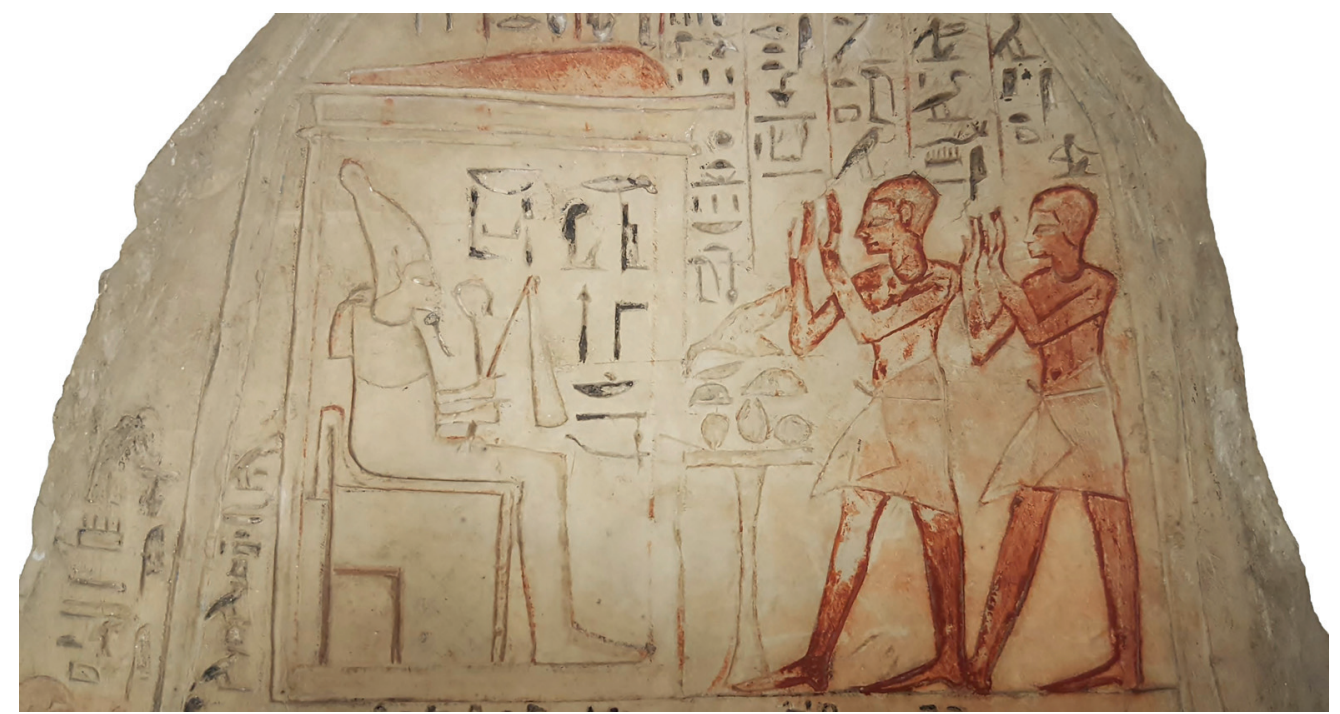

2. Upper register of the stela; not to scale (C) Egyptian Museum, Cairo).

the second and third gilded shrines of Tutankhamun. ${ }^{10}$ Similar to the $k 3 r$-shrine, the $p r-w r$ shrine was constructed to be used inside temples for housing images of gods and particularly that of Osiris. ${ }^{11}$

The twin doors of the $k 3 r$-shrine in this scene probably stand open at the front. Inside the shrine, before Osiris, are two short vertical lines of hieroglyphs in sunk reliefs reading:

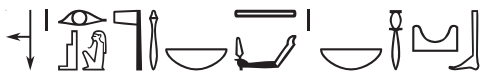

Wsir ntr 9 $n b \quad t 3 \underline{d} s r n b 3 b \underline{d} w$, 'Osiris, the great god, lord of the sacred land (i.e. the necropolis), lord of Abydos'.

Above the ceiling of the $k 3 r$-shrine, the beginning of the offering formula, invoking Osiris, is incised in three short vertical lines, delimited by incised lines from right to left, reading:

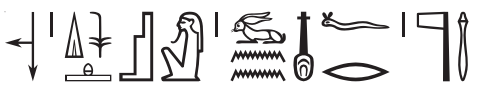

htp di nsw Wsir Wnn-nfr ntrr '3, 'An offering which the king gives to Osiris Wenennefer, the great god'.

On the right, Haremwia and his son Amenemopet are shown standing, facing left, with the right leg stepping forward, opposite the shrine of Osiris. They raise their hands before

\footnotetext{
10 Piankoff 1955: 42.

11 Spencer 1984: 112.
} 
their faces with the palms facing out in a pose of adoration. They are shown with closecropped hair and their skin is painted in a traditional reddish colour. They wear knee-length kilts with a triangular front showing a vertical line down the middle. The kilt is secured by a belt with a protruding knot. In front of Haremwia and Amenemopet is a table of offerings consisting of a tray and a high stand. It is heaped with a slaughtered goose and various kinds of bread.

The remaining part of the text of the offering formula continues in five vertical lines of inscription delimited by incised lines above the offering table, as well as the figures of Haremwia and Amenemopet. This text is incised in a retrograde arrangement of the usual orientation..$^{12}$ It is written from left to right, with the signs facing right, whereas the vertical lines are read from the left. In other words, it is oriented outwards to the right, in a reversal of the usual orientation. The text reads:

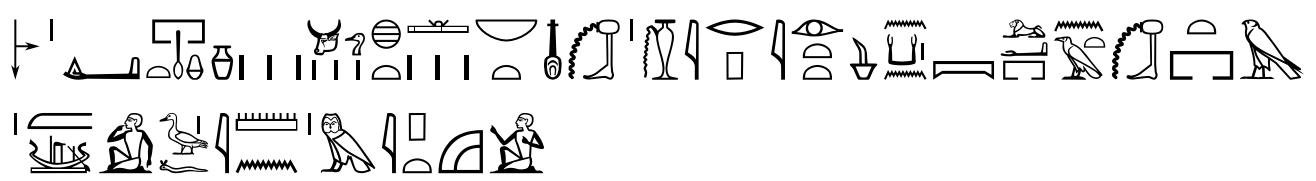

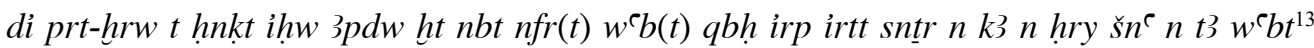
$H r-m-w i 3 s 3=f$ 'Imn-m-ipt, 'May (He, i.e. Osiris) give invocation offerings of bread, beer, oxen, fowls, every good and purified thing, cool water, wine, milk and incense to the $k a$ of the chief of the provisioning sector ${ }^{14}$ of the temple workshop Haremwia, and his son Amenemopet'.

The unusual retrograde orientation of the offering formula is well attested in two other stelae from Abydos, namely stela British Museum, London (EA638) and stela Fitzwilliam Museum, Cambridge (E.SS. 40). ${ }^{15}$ The orientation of this text may find an explanation in the Twelfth Dynasty stela of Sehetepibre in the Egyptian Museum, Cairo (CG 20538), originally found to the west of the enclosure of Osiris' temple at Abydos. ${ }^{16}$ The figure

${ }^{12}$ Retrograde is the term used to describe the orientation of hieroglyphic writing in which the hieroglyphs face towards the end of the text, instead of towards the beginning, in contrast to the normal prograde writing. Retrograde writing occurs most often in texts written in vertical columns; see: Simpson 2017: 337. It is a matter of debate whether this text follows a reverse or retrograde format. I argue that it is written in retrograde style, with the signs facing right, whereas the columns are read from the left. Thus, the text follows the rules of this style of writing. For further information about retrograde writing, see: Simpson 2017: 337-345; Goelet 2010: $128-129$.

${ }^{13}$ For this title, see: Taylor 2001: 47.

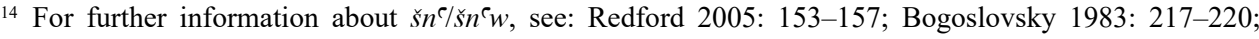
Savelieva 1993: 335-345. For the staff of a provisioning sector ( $\left.\Sigma{ }^{\subsetneq}\right)$, see: Stefanović 2010: 313-319.

${ }^{15}$ For further information about these stelae and the retrograde writing of their offering formula, see: Hallmann 2015: 131-133, 141-145, n. 34, Figs 1-2. Hallmann argues that both stelae date to the beginning of the Twenty-seventh Dynasty; see: Hallmann 2015: 151-152.

${ }^{16}$ Lange, Schäfer 1902: Pl. 40; see also the stela of Mentuhotep in the Egyptian Museum, Cairo (CG 20539), from the area to the west of the enclosure of Osiris' temple at Abydos, where the texts on the recto and verso of the stela address the temple (Lange, Schäfer 1902: Pls 41-42; Fischer 1977: 24). 
of Osiris and the hieroglyphic texts on the recto and verso of Sehetepibre's stela face in the same direction, towards the nearby Temple of Osiris. ${ }^{17}$ Similarly, Osiris' figure, name and the text of the offering formula on Haremwia's stela are probably oriented towards the Temple of Osiris at Abydos. The latter is the place where both stelae were erected. Therefore, this indicates a consistency between the textual sequence and geographical orientation, which is the likely reason for this unusual retrograde orientation. This explanation also seems logical, consistent and applicable to the figure of the brewer Amenemopet, who is shown standing alone, probably facing the Temple of Osiris, in an adoration pose outside the margins of the stela on the left of the second register.

\section{SECOND REGISTER}

The second (bottom) register is divided into two parts with two - separated by a vertical incised line - groups of members of Haremwia's family, facing each other (Fig. 3). On the right is a figure of unclear sex, facing left, almost naked except for a girdle around the genitals. The figure's head is turned backwards looking at her/his mother Tjera, who is shown behind, breastfeeding her infant daughter. She/He holds two long stemmed lotus plants in both hands. The filiation caption above the figure's head reads, $\longrightarrow$ \{ $\left.\left.1\right|^{18} s\right\}=s$, 'her son'. Erika Feucht argues that most probably this was a girl. According to her, this is corroborated by some details: the fact that the genitals were veiled by the girdle around the hips, and the right leg slightly stepping forward. ${ }^{19}$ Feucht adds that in the tombs of Deir el-Medina, the omission of the feminine letter $\square t$ in genealogical statements is common. ${ }^{20}$ The argument of Feucht seems reasonable, as this figure is not shown with the sidelock of youth. ${ }^{21}$ Furthermore, there are similarities between this figure and that of the infant daughter being breastfed by Tjera.

The matrilineal filiation formula and name of the infant daughter, on the lap of Tjera, are incised in sunk relief above her head and in front of her mother's face, reading,

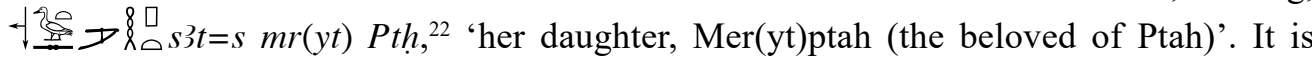
striking that the daughter's name is written in reverse orientation from right to left. This is probably consistent with her figure as she is shown facing right. Her mother has the Asiatic name $\longrightarrow$ II 1 Tyr ( $\operatorname{Tr}$ ?), 'Tjera' beneath her figure. She was probably the wife of Amenemopet. ${ }^{23}$ Tjera's right arm is shown above the head of her daughter with the forearm hanging down her back. The daughter's pose with upright torso shows that her mother Tjera supports her back. Another woman, facing left, is shown behind Tjera

17 Fischer 1977: 24.

${ }^{18}$ The letter $(s)$ is reversed.

${ }^{19}$ Feucht 1995: 155, n. 768.

${ }^{20}$ Feucht 1995: 155, n. 768.

${ }^{21}$ The sidelock of youth was used to distinguish boys from girls; see: Tassie 2009: 457.

${ }^{22}$ The biliteral sign $m r$ and the name $P$ th are inscribed in a reverse orientation.

${ }^{23}$ Schneider argues that Tjera is one of the relatives of Haremwia. For her identity and the etymology of her name, see: Schneider 1992: 253 (N 542). 


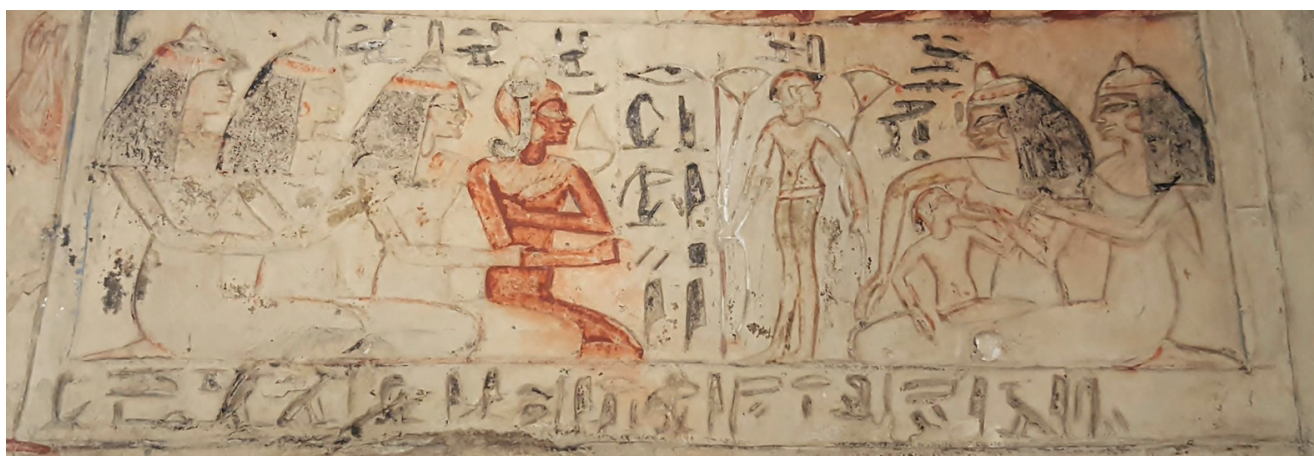

3. Lower register of the stela; not to scale (C Egyptian Museum, Cairo).

supporting her with both arms. The two women are shown as if seated. Their Asiatic names

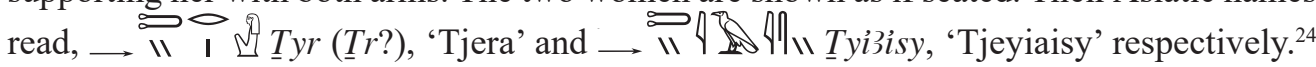
The names of both women are incised in sunk relief beneath their figures, within the bottom marginal lines. They wear long tight garments, wsh-collars around their necks, earrings and identical long wigs, with massive side braids, painted black and topped by fillets and cones of fat.

Only a few stelae show a naked child being breastfed. ${ }^{25}$ A relief fragment dated to the Old Kingdom shows a mother breastfeeding her child, who is shown seated upright on her lap. ${ }^{26}$ A few other examples date to the New Kingdom including the Eighteenth Dynasty stela (EA804). ${ }^{27}$ This shows a child called Merysekhmet on the lap of his mother, embraced by her ${ }^{28}$ Furthermore, stela Cairo CG 34125 shows a child being breastfed by his mother. ${ }^{29}$ The New Kingdom stela Cairo CG 34182 shows a woman breastfeeding her child, who is depicted seated upright on her lap. ${ }^{30}$

The discussed representation is also reminiscent of scenes from other monuments, which show a mother breastfeeding an infant in a shelter, called birth arbour. ${ }^{31}$ For instance, a limestone ostracon from Deir el-Medina shows a sketch for a wall painting depicting a young woman

${ }^{24}$ The letter $s$ in this name is reversed and the name itself has no determinative. For the name and its etymology, see: Schneider 1992: 248 (N 529).

${ }^{25}$ For further information about breastfeeding in ancient Egypt, see: Strouhal, Vachala, Vymazalová 2014: 191-193.

${ }^{26}$ Stela Princeton 918; see: Ranke 1950: 228-236. See also the scene of a mother breastfeeding a baby in the Fifth Dynasty tomb of Niankhkhnum and Khnumhotep at Saqqara: Graves-Brown 2010: 66.

27 British Museum: inv. no. EA804.

28 Budge 1914: 13, Pl. 50.

29 Lacau 1926: 176, Pl. 54.

${ }^{30}$ Lacau 1926: 222-224, Pl. 69. For the motif of a child on a person's lap in New Kingdom iconography and scenes with royal children sitting upright on their nurse's lap being breastfed, like Princess Tia, daughter of Thutmose IV, with her nurse Meryt, see: Ockinga, Binder 2013: 510-511; see also: Metawi 2018: 40, n. 48. For the iconographic motif of a child being breastfed in New Kingdom stelae, see: Maruéjol 1983: 314-315.

31 For a discussion of 'Wochenlaube' or 'birth arbour' and its function, see: Toivari-Viitala 2001: 175-176. 
seated in a vine-covered arbour nursing an infant. ${ }^{32}$ A limestone relief from the tomb of Mentuemhat at Thebes (TT 34) shows a woman nursing her child between two trees. ${ }^{33}$ These scenes call to mind Isis suckling Horus and the story of their concealment in the Delta marshes of Khemmis. ${ }^{34}$

On the right of the second group and facing right is a naked young man painted reddish. He is shown as if seated with the sidelock of youth, ${ }^{35}$ and a cone of fat on his head. ${ }^{36}$ He wears a wsh-collar around his neck. His left arm is bent across the chest with a clenched fist holding a lotus flower before his nose. His right arm is extended forward with clenched fist. The patrilineal filiation formula above his figure reads, $\vdash$ ? $s 3=f$, 'his son'. In front

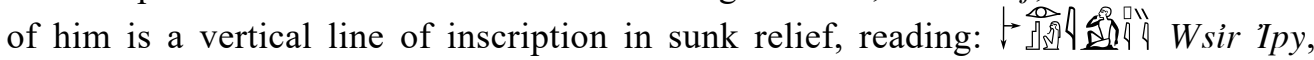
'the Osiris Ipy'. The title 'Osiris' before his name demonstrates that he is a deceased son of Haremwia. He is also the only figure on the stela shown holding a lotus flower to his face. ${ }^{37}$

Beneath his figure a Semitic name reads, $\rightarrow$ I I I I I Iry, 'Iry', who was probably a daughter or son of Amenemopet and the granddaughter/son of Haremwia. ${ }^{38}$ Iry is most probably the name given to the almost naked standing figure holding two long stemmed lotus, depicted further to the right. However, the name is not inscribed beneath the figure. It is oriented to the right probably because she/he is shown turning the head to the right.

Ipy is followed by three women who are shown as if seated. They wear long tight garments, wsh-collars around their necks, earrings and identical long wigs, with massive side braids, topped by fillets with lotus flowers and cones of fat. Their names are written beneath them, between the bottom marginal incised lines. The matrilineal filiation formula of the first woman from the right reads, $\longrightarrow$ ? latter is a good Egyptian name given to women of foreign origin. ${ }^{39}$ The matrilineal filiation of the second woman reads, $\rightarrow$ t

32 This ostracon is now on display in the British Museum, London (EA8506). It dates to the Nineteenth or Twentieth Dynasty; see: Russmann 2001: 67; Demarée 2002: 21, Pl. 49.

33 This relief dates to the Twenty-fifth or Twenty-sixth Dynasty. It is now on display in the Brooklyn Museum 48.74; see: Cooney 1950: 193-194, P1. 14; Fazzini et al. 1989: no. 71.

34 See: Metternich stela (Allen 2005: 51, Fig. on p. 52, detail of the right side, verso of the stela), and an openwork glazed composition spacer-bars, from Third Intermediate Period jewellery, now on display in the British Museum, London (EA26233; Andrews 1994: 101, Fig. 101a). For the concealment and birth of Horus in the Khemmis Marshes, see: Gardiner 1944: 52-58; Bergman 1968: 137-140; Altenmüller 1975: 921-922; Klasens 1952: 64-78.

35 For further information about the sidelock of youth and its significance, see: Tassie 2005: 65-73.

36 The same coiffure is shown on the late Eighteenth Dynasty stela of Satpair, dedicated by Nakhy, now in the British Museum, London (EA360); see: Hall 1925: 7, P1. 14.

37 Feucht 1995: 155, n. 769.

38 Schneider 1992: 33 (N 48).

39 For this name, see: Hoffmeier 1996: 94, n. 191. 
$\mathrm{Ta}<\mathrm{i}>$ agem(?)' ${ }^{40}$ The spelling of this Asiatic name is problematic. Thomas Schneider mentions three possible readings, namely $T 3-3(?)-g-m$, the Egyptian pronunciation $3 t-3 g-3 m($ ?), as well as the hypothetical pronunciation $T 3-<i>3-g-m .{ }^{41}$ The two women are likely the sisters of Amenemopet and daughters of the third woman called Gaga, whose titles and Asiatic name are incised above her head reading, $\forall-0 \square \Delta \Delta \omega t=f n b t$ $\operatorname{pr} G 3 g$ 3, 'his mother, the lady of the house Gaga' ${ }^{42}$ The suffix pronoun $f$ in Gaga's caption is likely referring to her deceased son Ipy.

On the left, behind Gaga, is the figure of Amenemopet, the son of Haremwia and Gaga. $\mathrm{He}$ is shown standing alone outside the marginal lines of the stela. Like his figure on the first register, he raises both hands before his face, with the palms facing out in a pose of adoration. The caption above his head reads, $\vdash$ 负 brewer Amenemopet'. The latter worked as a brewer in the same provisioning sector $(\check{s} n)$, over which his father presided. ${ }^{43}$

The figure of Amenemopet on the second register does not face Osiris inside his shrine. He is probably facing the Temple of Osiris at Abydos or simply shown adoring his family. Thus, the striking representation of Amenemopet and his prominence suggest that he may have had the stela manufactured or that he commissioned it. ${ }^{44}$ This may explain his double representation and particularly his figure behind his father on the first register, which is likely to be a reflection of the men's professional association that took precedence over family links. Due to this, Gaga, the wife of Haremwia is not shown behind her husband as it was common in several New Kingdom stelae..$^{45}$

\section{ANALYSIS AND CONCLUSIONS}

Although Haremwia is a proper Egyptian name, most of his relatives named on the stela have Asiatic names. The owner of this stela is not attested in Ranke, Personennamen. ${ }^{46}$

${ }^{40}$ For the name $\mathrm{Ta}<\mathrm{i}>$ agem and its etymology, see: Schneider 1992: 226 (N 476). For further information about foreign children in ancient Egypt, see: Feucht 1990: 177-204. For elite and non-elite foreign children labour in New Kingdom temple workshops, see: Matić 2017: 53-63.

41 Schneider 1992: 226-227 (N 476).

42 For the name Gaga and its etymology, see: Schneider 1992: 225 (N 474). Gaga is Babylonian god and possibly one of the twenty-five deities in the Assyrian pantheon mentioned in one of Sennacherib's inscriptions; see: Bøe 2001: 95. This name is mentioned in $P N$ as $G g$; see: PN I: 352.21; PN II: 166.

43 Polz 1990: 49. It is interesting that the owner of the Eighteenth or Nineteenth Dynasty stela London, University College (UC 14233) was a brewer named Amenemopet. The latter's stela was excavated from the Ramesseum and it shows him presenting offerings to the son of king Ahmose who is called Ahmose-Sipair. For this stela, see: PM I.2² , 681; Stewart 1976: 47, P1. 37 (3). For the dating of this stela, see: Demarée 1983: 169.

44 The owner of the monument is usually represented more prominently than the other figures; see: Roth 1999: 50 .

45 Several New Kingdom stelae show the owner followed by his wife standing in adoration pose before Osiris; see: stelae Cairo CG 34055, 34064, 34068, 34070-34073, 34077, 34082, 34086, 34090, 34093-34095, 34097, 34133; Lacau 1926: Pls 33, 38-39, 42-45, 47, 55.

${ }^{46}$ The name is given to other individuals, see: $P N$ I: 247.18 . 
The same name is given, however, to different individuals on a few other monuments. ${ }^{47}$ These are, however, not dated to the Eighteenth Dynasty, except for one stela in the British Museum, which does not belong to him. ${ }^{48}$ Thus, very little information is known about Haremwia.

\section{ICONOGRAPHIC TRAITS}

The style of the figures, the characteristic types of clothes and wigs on this stela are regarded as indicating a date from mid to late Eighteenth Dynasty. ${ }^{49}$ The long wigs with massive side braids, topped by fillets and cones of fat, were very common during the Eighteenth Dynasty, and particularly in the reign of Amenhotep III, as they are shown on several stelae dating from the same period. ${ }^{50}$ This type of wig was also common in Theban tombs dating to the Eighteenth Dynasty, like the tombs of Nakht and his wife Tawy (TT 52), ${ }^{51}$ Djeserkareseneb (TT 38), ${ }^{52}$ and the anonymous tomb (TT 175). ${ }^{53}$ Moreover, the $̌ n$-sign and the vessel beneath it on the triangular top can be used as date indicators, as they are shown on top of many New Kingdom stelae. ${ }^{54}$

The torsos of the standing figures are disproportionally short in relation to their lower bodies, with their backs and hips in an s-like shape. These body proportions are regarded as characteristic of representations dating to the reign of Amenhotep III. ${ }^{55}$ Furthermore, the faces in profile show tip-titled noses similar to those in the royal tomb of Amenhotep III in the Valley of the Kings (KV 22), as well as in private tombs dating from his reign. ${ }^{56}$

47 See: James (Ed.) 1970: 30-31, 40-41, Pls 26, 35 (2); PN I: 247.18.

48 It is a limestone stela of the 'hearer of plaints of the Lord of the Two Lands in the Place of Truth' and his beloved son Paneferemnekht worshipping the sacred goat of Mendes; see: Budge 1914: 11, Pl. 42.

49 Feucht 1995: 155

50 See, for instance, the British Museum Eighteenth Dynasty stelae of Bati and her mother Henutnefert (EA280), Nakht and Ahmose (EA1318); Budge 1914: 12-13, Pls 47, 49; see also: the stelae of Apu (EA295), Djehutymes (EA155), Thuthu (EA301), Auna (EA1332); Edwards (Ed.) 1939: 38-40, 42, 47-51, Pls 33, 36, 39, 41. See also the stelae of Ptahmai and his family (EA324), Tamait and her daughter Kya (EA644), Pashed (EA282), Karei (EA294), and the anonymous unfinished stela (EA339); Hall 1925: 7-9, 14, Pls 14-15, 19, 24, 48. For this type of wig, see: stelae Cairo CG 34055, 34057, 34062, 34068, 34070; Lacau 1926: Pls 33-34, 37-38.

51 The tomb dates to the reign of Thutmose IV and Amenhotep III; see: Davies 1917: Pls 8, 12, 16-18.

52 The tomb dates to the reign of Thutmose IV and Amenhotep III; see: Davies 1963: Pls 1, 6-7.

53 The tomb dates to the reign of Thutmose IV; see: PM I.1 ${ }^{1}, 281$; Manniche 1988: 31-44. For this type of wig, see: Manniche 1988: 39, Figs 40-42.

${ }^{54}$ Demarée 1983: Pls 2 (A 3), 3 (A 5, 8), 5 (A 15, 16), 7 (A 22, 25-26), 8 (A 28-30), 9 (A 32-33); see also: stelae Cairo CG 34071-34073, 34075-34076, 34082-34083; Lacau 1926: Pls 39, 42.

55 Metawi 2018: 40.

${ }^{56}$ Metawi 2018: 40, n. 41. 


\section{PhraseOLOGICAL TRAITS}

The title hry $\check{s} n^{\complement}$ is attested on other monuments dating to the Eighteenth Dynasty, but none of them mentions the temple or complex in which the provisioning sector $\left(\check{s} n^{\tau}\right)$ is located. ${ }^{57}$ It is striking that $t 3 w^{c} b t$ in the owner's title hry šn $n^{\ulcorner} n t 3 w^{c} b t$ is not specific and does not refer to any temple.$^{58}$ Therefore, the title raises the question about the nature of $t 3 w^{c} b t$ and its function. The term $w^{c} b t$ frequently means a 'place of embalming or house of purification', located either in the pyramids' valley temples or in the royal funerary complexes. ${ }^{59}$ Thomas Schneider argues that it means here 'reinen Stätte', 'pure place', which is the literal meaning of the word. ${ }^{60}$ However, the complex where the $w^{c} b t$ was located is not stated in the title.

On the basis of scenes and texts in private tombs, many Egyptologists argued that the term $w^{`} b t$ should designate a 'mortuary workshop' for the construction and decoration of tombs, as well as the production of various goods for the deceased's benefit in the afterlife, including statues and funerary furniture. ${ }^{61}$ However, Massimiliano Nuzzolo argues that the $w^{\text {' }} b t$ seems rather a 'temple workshop' associated with the manufacture of cult statues and more generally with production of other cultic materials. ${ }^{62} \mathrm{He}$ adds that the $w^{c} b t$ was probably located in the temple itself. ${ }^{63}$

Abdul Rahman Al-Ayedi argues that $t 3 w^{c} b t$ means 'the workshop' ${ }^{64}$ Thus, he translated the title of Haremwia as 'chief of the provisioning quarters of the workshop'. ${ }^{65}$ Al-Ayedi could be referring in his translation to the temple workshop. On the other hand, he gives the meaning of 'provisioning quarters' for $\breve{s}$ ' indicating their function as economic temple complexes containing many sections, namely bakery, brewery, pottery and sometimes a kitchen for cooking meat or roasting fowls. ${ }^{66}$ In the New Kingdom, the word $\check{s}^{c}$ was used to designate production centres for the processing of basic foodstuffs. They formed

57 This title is mentioned on the stela of Paser from Abydos, dating to the reign of Thutmose III (Cairo CG 34038), stela of Me`y from Saqqara, dating to the reign Thutmose III or Amenhotep II (Cairo CG 34050); see: Lacau 1926: 72-73, 86-90; Polz 1990: 54-55. It is also recorded in inscriptions on a pot from Malkata palace, dating to the reign of Amenhotep III; see: Hayes 1951: 51, Fig. 11, 1. 150; Polz 1990: 55. The title is also found in a docket from Amarna, dating to the reign of Akhenaten; see: Polz 1990: 56.

58 Polz 1990: 48.

${ }^{59}$ For $w^{`} b t$, 'place of embalmment', see: $W b$ I, 284; Faulkner 1972: 57. Donohue argues that $w^{\complement} b t$ is loosely rendered 'place of embalmment'; see: Donohue 1978: 143, n. 6, 145, n. 1. In P. Cairo Calendar no. 86637, rt. IX, 2; X, 11; XIII, 13; XXIV, 9, w`bt is the 'place of embalmment'; see: Bakir 1966: 19-20, 23, 34, 100. See also: Shore 1992: 232.

60 Schneider 1992: 225.

${ }^{61}$ Nuzzolo 2016: 60. For further information about the $w^{\top} b t$ as a workshop, see: Coppens 2002a: 13-26; 2002b: 309-318.

62 The temple workshop has its own chief or overseer whose title was imy-r $w^{\complement} b t$, who was the chief of artisans and craftsmen of the temple workshop; see: Nuzzolo 2016: 60.

63 Nuzzolo 2016: 60.

64 Al-Ayedi 2006: 419, no. 1425.

65 Al-Ayedi 2006: 419, no. 1425.

${ }^{66}$ Savelieva 1993: 337. Based on the Middle Kingdom, Berlev describes the storehouses $\check{s}^{\ulcorner} w$ as places employed for storing provisions of great value; see: Berlev 1978: 319. 
an important element in the country's redistributive economy and are to be distinguished from storage centres. ${ }^{67}$ Therefore, it is better to translate $\check{s}^{c} n t 3 w^{c} b t$ in Haremwia's title as 'the provisioning sector of the temple workshop'.

All the daughters in this stela have matrilineal filiation captions referring to two women. ${ }^{68}$ The first is Tjera, who was probably the wife of Amenemopet, accompanied by her daughter or son Iry and her infant daughter Mer(yt)ptah. The second is Gaga, wife of Haremwia, preceded by her two daughters who have matrilineal filiation captions. It is evident that there was a preference for matrilineal filiations on Egyptian monuments. ${ }^{69}$ In many other cases, children are accompanied by matrilineal filiation captions without a mention of their fathers' names or the marital status of the mothers. ${ }^{70}$ Thus, the maternal lineage of those daughters is probably attributed to the roles of gender dominance. ${ }^{71}$ However, the patrilineal filiations of Amenemopet and Ipy may suggest a socio-religious function of the stela. On the one hand, Amenemopet's filiation reflects his professional association with his father Haremwia, which took precedence over family links, and on the other hand, Ipy's filiation may suggest that Haremwia dedicated this stela to his deceased son for funerary purpose. Thus, it was found at the south side of the central necropolis in Abydos and was probably set up near the Terrace of the Great God, overlooking the Temple of Osiris and the processional way leading to it.

As for the name Amenemopet, it first appeared during the Eighteenth Dynasty. ${ }^{72}$ It was very common from the Eighteenth Dynasty onwards, with the $\triangle$ ipt-sign that frequently appears in the writing of this name. ${ }^{73}$ Thus, it can be regarded as a date indicator.

\section{THE OCCURRENCE OF ASIATIC NAMES}

The stela of Haremwia interestingly records Asiatic names of the owner's family members. The identification of the names of foreign residents in Egypt is not always a simple matter, and it causes controversy among Egyptologists. ${ }^{74}$ In recording foreign names Egyptian scribes had a tendency to write down what they heard and not the actual pronunciation of these names. ${ }^{75}$ Thus, we are dealing with the oral transmission of such names, with the

${ }^{67}$ For $\breve{n^{c}} w^{c} b$ as temple constructions for the preparation of offerings and a back part for stocking and cult, see: Traunecker 1987: 147-162. For $p r-\varsigma n^{\complement}$ as a supportive economic sector, see: Goedicke 1967: 133; Helck 1975: 47.

${ }^{68}$ In other words, there is a repetition of the feminine suffix pronoun $s$ in the filiation formulae $s 3 t=s$ and $s 3=s$, 'her daughter and her son'.

69 Franke 1983: 317.

70 Stefanović 2011: 19.

71 Stefanović 2011: 23.

${ }^{72}$ PN I: 27.18. It means 'Amun is in Ipet'; see: Leprohon 2013: 191.

73 Ward refers to many occurrences of this name on various monuments; see: Ward 1986: 95, 141, n. 83.

74 For methods to recognise foreign names on monuments, see: Ward 1994: 63.

75 Ward 1994: 66. 
attendant phonetic problems. Therefore, anthroponymy is the most efficient method for identifying foreign residents living in Egypt. Moreover, analysis of the etymology of their names makes it possible to determine their origin. ${ }^{76}$ Thus, this helps to demonstrate the impact of other cultures on Egyptian society. ${ }^{77}$

The distinct languages of western Asia contained different phonemes from those of the Egyptian language. Thus, there remain specific problems in determining the origin of these phonemes. However, some of these names were Egyptianised, which is clear in the name $T 3-<i>3-g-m$, through the addition of the feminine definite article $T 3 .{ }^{78}$

The Asiatic names on this stela clearly show that the Egyptians regarded the foreigners of Asiatic origin as part of the Egyptian community. It is only through their foreign names that we know they are not of pure Egyptian origin. Most probably Egyptians did not give their children foreign names, ${ }^{79}$ and thus, persons with these names in ancient Egypt are either foreigners or are descendants of resident foreign ancestors. ${ }^{80}$ Consequently, Haremwia himself could be of non-Egyptian origin but could have assumed a proper Egyptian name, which was a regular practice during the New Kingdom. ${ }^{81}$ Thus, these Asiatic names may suggest the foreign origin of Haremwia. Furthermore, they were regarded as a reminder of the family's foreign origin.

The inhabitants of Egypt had always been ethnically diverse due to the existence of nonEgyptians in the army, and at the royal court, through extensive foreign trade and the import of slaves ${ }^{82}$ The population of Egypt during the New Kingdom shows a cosmopolitan and diverse society where non-Egyptians were integrated into the population at all levels. The Eighteenth Dynasty was a period of external contact that would have deeply affected the socio-cultural and religious affairs in Egypt. ${ }^{83}$ During the mid-Eighteenth Dynasty many officials had non-Egyptian members in their households, this being the result of Egyptian military and diplomatic activities abroad and notably in Asia ${ }^{84}$ During this dynasty, there were wide-ranging international contacts not only between Egypt and the neighbouring regions, but also throughout the eastern Mediterranean ${ }^{85}$ The occurrence of Asiatic names on this stela could demonstrate the permission given to foreigners in Egypt to trace their lineage. Similarly, foreign names are also attested on other Eighteenth Dynasty stelae from Abydos, namely the Cairo stelae of Ii-Baal (CG 34083), Paiamayai (CG 34115), and Ry (CG 34105). ${ }^{86}$

${ }^{76}$ Schneider 1993: 453.

77 Schneider 1993: 453.

78 Ward 1994: 70.

79 Ward 1994: 62.

${ }^{80}$ Ward 1994: 62-63.

81 Ward 1994: 64.

${ }^{82}$ Leahy 1995: 228-230. For the roles of different groups of foreign origin in the Egyptian society, see: Booth 2005 .

${ }^{83}$ Anthony 2017: 4.

${ }^{84}$ Darnell 2014: 271.

${ }^{85}$ Anthony 2017: 4.

${ }^{86}$ Lacau 1926: 132-133, 160, 168, Pls 42, 60. See also the Abydos stela of Karu, which records his Asiatic artisans. Two of the chief craftsmen on the stela appear to be of west Semitic origin and a third one is called the Asiatic $3 m$; see: Kitchen, Beltra 1990: Stela of Karu, Stela 21, Pl. 45. 
The stela does not suggest the place of residence of Haremwia's family. There is a possibility that his son's name Amenemopet, including the name of Amun, could point to the Theban region. On the other hand, the stela shows evidence for Abydos as its provenance, as it was likely oriented towards the Temple of Osiris at this cult centre. ${ }^{87}$

To summarise, the stela of Haremwia interestingly shows unique iconographic and palaeographic details, namely the double representation of Amenemopet and particularly his figure in adoration pose outside the marginal lines of the stela, the naked deceased young man named Ipy and the almost naked child Iry. It is the only monument, to the best of my knowledge, which records the title hry šn $n t 3 w^{\ulcorner} b t$, 'chief of the provisioning sector of the temple workshop'. It shows a peculiar retrograde orientation of specific texts in accordance with the orientation of the Temple of Osiris at Abydos and its processional way. Finally, it shows the family's professional association, with precedence given to the brewer Amenemopet.

\section{Acknowledgements}

I am grateful to Dr Emily Teeter, University of Chicago, for her valuable and helpful comments on an earlier draft of this paper. I am also grateful to Ms. Marwa Abd Elrazek, Head of the Registration Collection, Management and Documentation Department in the Egyptian Museum, Cairo, and the curators of the Grand Egyptian Museum, Giza, for their help and support. I would also like to thank James Christopher Cook for the English proofreading.

\section{References}

Al-Ayedi, A.R. 2006: Index of Egyptian Administrative, Religious and Military Titles of the New Kingdom, Ismailia

Allen, J.P. 2005: The Art of Medicine in Ancient Egypt, New York-New Haven-London

Allen, T.G. 1936: Egyptian Stelae in Field Museum of Natural History, AnthrSer XXIV/1, Chicago

Altenmüller, H. 1975: Chemmis. B, [in:] LÄ I, 921-922

Andrews, C. 1994: Amulets of Ancient Egypt, London

Anthony, F.B. 2017: Foreigners in Ancient Egypt: Theban Tomb Paintings from the Early Eighteenth Dynasty (1550-1372 BC), London

Bakir, A. 1966: The Cairo Calendar no. 86637, Cairo

Bergman, J. 1968: Ich bin Isis: Studien zum memphitischen Hintergrund der griechischen Isisaretalogien, Acta Universitatis Upsaliensis, HistRel (U) 3, Uppsala

Berlev, O.D. 1978: Общественные отношения в Египте эпохи Среднего царства: социальный слой “царских $h m w w$ ", Moscow

Bierbrier, M.L. (Ed.) 1982: HTBM 10, London

${ }^{87}$ Abydos was the residence of many Asiatic inhabitants; see: Saretta 2016: 161, n. 212. 
Bogoslovsky, E.S. 1983: Древнеегипетские мастера: по материалам из Дер эль-Медина, Moscow

Booth, C. 2005: The Role of Foreigners in Ancient Egypt: A Study of Non-stereotypical Artistic Representations, BAR-IS 1426, Oxford

Bøe, S. 2001: Gog and Magog: Ezekiel 38-39 as Pre-text for Revelation 19,17-21 and 20,7-10, Tübingen

British Museum: http://www.britishmuseum.org/research/collection_online/search.aspx (accessed August 16, 2020)

Budge, E.A. 1914: HTBM 5, London

Cooney, J.D. 1950: Three Early Saïte Tomb Reliefs, JNES 9/4, 193-203

Coppens, F. 2002a: A Variety of Designations: Some Terms for Wabet and Court in GraecoRoman Temples, $\mathrm{ArOr} 70 / 1,13-26$

Coppens, F. 2002b: The Wabet: An Old Kingdom Mortuary Workshop in a Graeco-Roman Temple?, ArOr 70/3, 309-318

Darnell, J.C. 2014: The Stela of the Viceroy Usersatet (Boston MFA 25.632), His Shrine at Qasr Ibrim, and the Festival of Nubian Tribute under Amenhotep II, ENiM 7, 239-276

Davies, N. de G. 1917: The Tomb of Nakht at Thebes, PMMA Egyptian Expedition I, New York

Davies, N.M. 1963: Scenes from Some Theban Tombs (Nos 38, 66, 162, with Excerpts from 81), PTT IV, Oxford

Demarée, R.J. 1983: The $3 h$ ikr $n R^{e}$-Stelae: On Ancestor Worship in Ancient Egypt, EgUit III, Leiden

Demarée, R.J. 2002: Ramesside Ostraca, London

Donohue, V.A. 1978: $P r-n f r, J E A$ 64, 143-148

Edwards, I.E.S. (Ed.) 1939: HTBM 8, London

Faulkner, R. 1972: A Concise Dictionary of Middle Egyptian, Oxford

Faulkner, R. 1973: The Ancient Egyptian Coffin Texts I. Spells 1-354, Warminster

Fazzini, R.A., Bianchi, R.S., Romano, J.F., Spanel, D.B. 1989: Ancient Egyptian Art in The Brooklyn Museum, New York

Feucht, E. 1990: Kinder fremder Völker in Ägypten II, SAK 17, 177-204

Feucht, E. 1995: Das Kind im Alten Ägypten: die Stellung des Kindes in Familie und Gesellschaft nach altägyptischen Texten und Darstellungen, Frankfurt-New York

Fischer,H.G. 1976: Archaeological Aspects of Epigraphy and Palaeography, [in:]Caminos, R.A., Fischer, H.G. (Eds), Ancient Egyptian Epigraphy and Palaeography, New York, $27-55$

Fischer, H.G. 1977: The Orientation of Hieroglyphs. Part I. Reversals, Egyptian Studies II, New York

Franke, D. 1983: Altägyptische Verwandtschaftsbezeichnungen im Mittleren Reich. Dissertation zur Erlangung der Würde des Doktors der Philosophie der Universität Hamburg, Ḧ̈S 3, Hamburg 
Gardiner, A.H. 1944: Horus the Behdetite, JEA 30, 23-60

Gardiner, A. 1957: Egyptian Grammar, London

Goedicke, H. 1967: Königliche Dokumente aus dem Alten Reich, $\ddot{A g} A b h$ 14, Wiesbaden Goelet, O. 2010: Observations on Copying and the Hieroglyphic Tradition in the Production of the Book of the Dead, [in:] D'Auria, S.H. (Ed.), Offerings to the Discerning Eye: An Egyptological Medley in Honor of Jack A. Josephson, CHANE 38, LeidenBoston, 121-132

Graves-Brown, C. 2010: Dancing for Hathor: Women in Ancient Egypt, London-New York Gülden, S.A. 2001: Die hieratischen Texte des P Berlin 3049, KÄT 13, Wiesbaden Hall, H.R. 1925: HTBM 7, London

Hallmann, A. 2015: Three Unusual Stelae from Abydos, JEA 101, 131-152

Hayes, W. 1951: Inscriptions from the Palace of Amenhotep III (Part 1), JNES 10/1, $35-56$

Helck, W. 1958: Zur Verwaltung des mittleren und neuen Reichs, Probläg 3, Leiden

Helck, W. 1975: Wirtschaftsgeschichte des alten Ägypten im 3. und 2. Jahrtausend vor Chr., $\mathrm{HbOr}$ 1, Leiden-Köln

Hermann, A. 1940: Die Stelen der thebanischen Felsgräber der 18. Dynastie, ÄgForsch 11, Glückstadt

Hodjash, S.I., Berlev, O.D. 1975: Several Middle Kingdom Stelae of the Moscow Fine Arts Museum, AltorForsch 3, 5-18

Hoffmeier, J.K. 1996: Israel in Egypt. The Evidence for the Authenticity of the Exodus Tradition, New York-Oxford

Holmberg, M.S. 1946: The God Ptah, Lund

James, T.G. (Ed.) 1970: HTBM 9, London

Kitchen, K.A., preparado com a colaboraçao da Beltrao, M.C. 1990: Catálogo da Coleçao do Egito Antigo existente no Museu National, Rio de Janeiro / Catalogue of the Egyptian Collection in the National Museum, Rio de Janeiro, Warminster

Klasens, A. 1952: A Magical Statue Base (Socle Béhague) in the Museum of Antiquities at Leiden, OMRO 33, Leiden

Lacau, P. 1926: Stèles du Nouvel Empire, Catalogue général des antiquités égyptiennes du musée du Caire Nos 34065-340186, Cairo

Lange, H.O., Schäfer, H. 1902: Grab- und Denksteine des Mittleren Reichs im Museum von Kairo, Catalogue général des antiquités égyptiennes du musée du Caire ${ }^{\circ s} 20001-$ 20780, Berlin

Leahy, A. 1995: Ethnic Diversity in Ancient Egypt, [in:] Sasson, J.M. (Ed.), Civilisations of the Ancient Near East 1, New York, 225-234

Leprohon, R.J. 2013: The Great Name: Ancient Egyptian Royal Titulary, Writings from the Ancient World 33, Atlanta

Manniche, L. 1988: The Wall Decoration of Three Theban Tombs (TT 77, 175, and 249), CNIP 4, Copenhagen

Mariette, A. 1880: Catalogue général des monuments d'Abydos découverts pendant les fouilles de cette ville, Paris 
Maruéjol, F. 1983: La nourrice : un thème iconographique, ASAE LXIX, 311-319

Matić, U. 2017: "The Best of the Booty of His Majesty": Evidence for Foreign Child Labour in New Kingdom Egypt, [in:] Langer, C. (Ed.), Global Egyptology: Negotiations in the Production of Knowledges on Ancient Egypt in Global Contexts, GHP Egyptology 26, London, 53-63

Metawi, D. 2018: The Stela of the Outline Draftsman $T n r$ and His Family (Cairo Museum JE 18924), JNES 77/1, 31-40

Nuzzolo, M. 2016: An Enigmatic Graffito from the Sun Temple of Nyuserre and the Meaning of the So-called "Slaughterhouse", PES XVII, 52-66

Ockinga, B., Binder, S. 2013: Fragments of an Amarna-age Stele in the Teti Pyramid Cemetery North, EtudTrav XXVI/2, 501-516

Piankoff, A. 1955: The Shrines of Tut-Ankh-Amon, BollSer XL/2, New York

Piankoff, A. 1957: Mythological Papyri, Texts, BollSer XL/3, New York

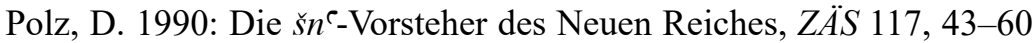

Ranke, H. 1950: Ein ägyptisches Relief in Princeton, JNES 9/4, 228-236

Redford, D.B. 2005: A Statuette of an Overseer of the Department of Food Production of the House of Amun, JSSEA 32, 153-157

Roeder, G. 1926: Ramses II. als Gott nach dem Hildesheimer Denksteinen aus Horbeit, ZÄS 61, 57-67

Roth, A.M. 1999: The Absent Spouse: Patterns and Taboos in Egyptian Tomb Decoration, JARCE XXXVI, 37-53

Russmann, E.R. 2001: Eternal Egypt: Masterworks of Ancient Art from the British Museum, London

Saretta, P. 2016: Asiatics in Middle Kingdom Egypt. Perceptions and Reality, LondonNew York

Savelieva, T. 1993: Houses $\breve{n}^{\varsigma} w$ in the Old Kingdom Temple Economy Considered in the Light of the Abu-Sir Papyri, [in:] Kormysheva, E.Y. (Ed.), Ancient Egypt and Kush: In Memoriam Mikhail A. Korostovtsev, Moscow, 335-345

Schneider, T. 1992: Asiatische Personennamen in ägyptischen Quellen des Neuen Reiches, $O B O$ 114, Freiburg-Göttingen

Schneider, T. 1993: Asiatic Personal Names from the New Kingdom: An Outline with Supplements, [in:] Sesto Congresso Internazionale di Egittologia, vol. 2, Torino, $453-470$

Shore, A.F. 1992: Human and Divine Mummification, [in:] Lloyd, A.B. (Ed.), Studies in Pharaonic Religion and Society in Honour of J. Gwyn Griffiths, EES-OP 8, London, 226-235

Simpson, R.S. 2017: Retrograde Writing in Ancient Egyptian Inscriptions, [in:] Jasnow, R., Widmer, G. (Eds), Illuminating Osiris: Egyptological Studies in Honor of Mark Smith, MVCAE 2, Atlanta, 337-345

Smith, M. 2017: Following Osiris. Perspectives on the Osirian Afterlife from Four Millennia, Oxford

Spencer, P. 1984: The Egyptian Temple: A Lexicographical Study, London 
Stefanović, D. 2010: The Late Middle Kingdom Stela of the Staff of Provisioning Sector ( $\check{n}^{\circ}$ ) (Musées d'art et d'histoire, Genève 6875), SAK 39, 313-319

Stefanović, D. 2011: When are Children Called "Her Children"?, ChronEg 86, 15-31

Stewart, H.M. 1976: Egyptian Stelae, Reliefs and Paintings from the Petrie Collection. Part One: The New Kingdom, Warminster

Strouhal, E., Vachala, B., Vymazalová, H. 2014: The Medicine of the Ancient Egyptians, vol. 1: Surgery, Gynecology, Obstetrics, and Paediatrics, Cairo-New York

Tassie, G. 2005: Single Mother Goddesses and Divine Kingship: The Sidelock of Youth and the Maternal Bond, [in:] Cooke, A., Simpson, F. (Eds), Current Research in Egyptology II: January 2001, BAR-IS 1380, Oxford, 65-74

Tassie, G. 2009: Hairstyles Represented on the Salakhana Stelae, [in:] DuQuesne, T. (Ed.), The Salakhana Trove: Votive Stelae and Other Objects form Asyut, $O C E$ 7, London, 459-536

Taylor, J.A. 2001: An Index of Male Non-royal Egyptian Titles, Epithets \& Phrases of the $18^{\text {th }}$ Dynasty, London

Toivari-Viitala, J. 2001: Women at Deir el-Medina. A Study of the Status and Roles of the Female Inhabitants in the Workmen's Community during the Ramesside Period, EgUit 15, Leiden

Traunecker, C. 1987: Les « temples hauts » de Basse Époque : un aspect du fonctionnement économique des temples, $R d E$ 38, 147-162

Ward, W.A. 1986: Essays on Feminine Titles of the Middle Kingdom and Related Subjects, Beirut

Ward, W.A. 1994: Foreigners Living in the Village, [in:] Lesko, L.H. (Ed.), Pharaoh's Workers: The Villagers of Deir el Medina, London, 61-86

Westendorf, W. 1966: Altägyptische Darstellungen des Sonnenlaufes auf der abschüssigen Himmelsbahn, MÄS 10, Berlin

Willems, H. 1997: The Embalmer Embalmed. Remarks on the Meaning of the Decoration of Some Middle Kingdom Coffins, [in:] Dijk, J. van (Ed.), Essays in Honour of Herman te Velde, Egyptological Memoirs 1, Groningen, 343-372 


\section{ÉTUDES et TRAVAUX XXXIII / 2020}
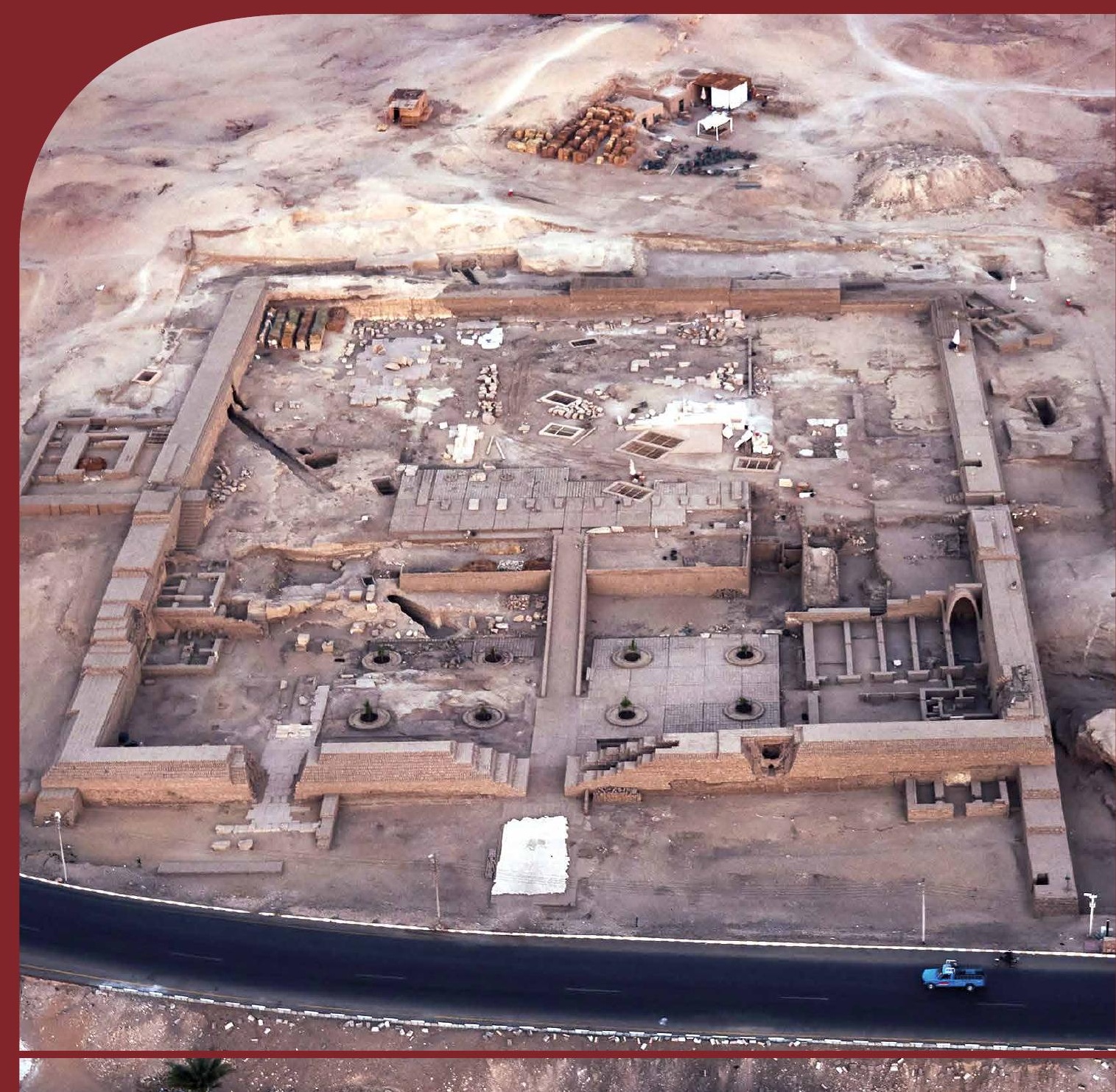

BOPIKSiO Institut des Cultures Mediterranéennes et Orientales IST PAN de l'Académie Polonáise des Sciences 


\title{
COMITÉ DE RÉDACTION SCIENTIFIQUE
}

Maciej Makowski - rédacteur en chef Jadwiga Iwaszczuk - rédacteur

Agnieszka Ryś - secrétaire de la rédaction

Ewa Laskowska-Kusztal - rédacteur thématique du volume

CONSEIL SCIENTIFIQUE DU JOURNAL

Michał Kobusiewicz (IAE PAN, Warszawa)

Ewa Laskowska-Kusztal (IMOC PAS, Warszawa)

Demetrios Michaelides (University of Cyprus, Nicosia)

Jean-Charles Moretti (IRAA-MOM, Université de Lyon 2/CNRS)

Dietrich Raue (Ägyptisches Museum der Universität Leipzig)

Paul Reynolds (ICREA, España)

Derek Welsby (British Museum, London)

COMITÉ SCIENTIFIQUE DE LECTURE

la liste des membres du comité est accessible en ligne sur

http://www.etudesettravaux.iksiopan.pl

\author{
RÉDACTION TECHNIQUE \\ Jadwiga Iwaszczuk \\ Maciej Makowski
}

REVUE DES TEXTES EN ANGLAIS

Jo Harper 
ÉTUDES et TRAVAUX XXXIII 
INSTYTUT KULTUR ŚRÓDZIEMNOMORSKICH I ORIENTALNYCH POLSKIEJ AKADEMII NAUK

\title{
STUDIA i PRACE
}

XXXIII

\author{
ROIKŚSiO \\ ESOPAN \\ WARSZAWA \\ 2020
}


INSTITUT DES CULTURES MÉDITERRANÉENNES ET ORIENTALES DE L'ACADÉMIE POLONAISE DES SCIENCES

\section{ÉTUDES et TRAVAUX}

XXXIII

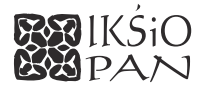

VARSOVIE

2020 
Publication scientifique financée dans le cadre du programme du Ministre de la Science et de l'Éducation Supérieure

« Programme National de Développement de l'Humanistique » pour les années 2016-2021 (projet no 3bH 150099 83)

\title{
NARODOWY PROGRAM ROZWOJU HUMANISTYKI
}

\author{
Copyright (C) \\ Instytut Kultur Śródziemnomorskich i Orientalnych PAN \\ et les Auteurs \\ Warszawa 2020
}
ISSN 2084-6762
(jusqu'en 2011 : 0079-3566)
e-ISSN 2449-9579
Version première en papier, imprimée en Pologne - 150 copies
Version électronique accessible sur
http://www.etudesettravaux.iksiopan.pl

Édition: Polskie Towarzystwo Historyczne et Wydawnictwo Neriton, Warszawa

Conception générale de la couverture : J. Iwaszczuk

Photographie de couverture : J. Pablo Moreira (C) Thutmosis III Temple Project

(Henket-ankh, le temple des Millions d'Années de Thoutmosis III, Louxor) 


\section{Table des matières}

Editorial (par Ewa Laskowska-Kusztal) ................................................................... 7

MirosŁaW BARWIK

Two Portraits of Senenmut in the Hatshepsut Temple at Deir el-Bahari

MirosŁaW BARWIK

New Prayers and Invocations to Hathor among Unpublished Dipinti

from the Thutmose III Temple at Deir el-Bahari

LiNDA CHAPON

The Decoration of the Columns and Pillars from the Henket-ankh of Thutmose III

(Western Thebes)

Abraham I. Fernández Pichel

Quelques blocs ptolémaïques inédits de la cour du IX pylône du domaine

d'Amon à Karnak

Amgad Joseph

The Stela of Haremwia, Chief of the Provisioning Sector of the Temple Workshop

(CG 34079 / JE 22011)

EWA JÓZEFOWICZ

Ramesside Inscriptions and Preparatory Sketches in the Western Wall of Portico

of Obelisks of Hatshepsut's Temple at Deir el-Bahari

Miral LASHiEN

Donkeys in the Old and Middle Kingdoms According to the Representations

and Livestock Counts from Private Tombs

AleKsandra Pawlikowska-Gwiazda

Christian Secondary Epigraphy in the Temple of Hatshepsut. Some New Remarks

KRZYSZTOF RADTKE

Square Grids in the Tomb of Akhethotep - Questions and Doubts

Myriam Seco Álvarez, JaVIER Martínez Babón

The Temple of Millions of Years of the Pharaoh Thutmose III (Luxor). An Update on the Research 